\title{
Vaccinia peptides eluted from HLA-DR1 isolated from virus- infected cells are recognized by CD4+ $T$ cells from a vaccinated donor
}

\author{
Iwona Strug ${ }^{1}$, J. Mauricio Calvo-Calle ${ }^{1}$, Karin M. Green ${ }^{2}$, John Cruz $^{3}$, Francis A . Ennis ${ }^{3}$, \\ James E. Evans ${ }^{2}$, and Lawrence J. Stern ${ }^{1,4,{ }^{*}}$ \\ ${ }^{1}$ Department of Pathology, University of Massachusetts Medical School, Worcester, MA 01655 \\ 2 Proteomic \& Mass Spectrometry Core Facility, University of Massachusetts Medical School, \\ Worcester, MA 01655 \\ ${ }^{3}$ Center for Infectious Disease and Vaccine Research, University of Massachusetts Medical \\ School, Worcester, MA 01655 \\ ${ }^{4}$ Department of Biochemistry \& Molecular Pharmacology, University of Massachusetts Medical \\ School, Worcester, MA 01655
}

\begin{abstract}
Class II MHC proteins bind peptides and present them to CD4+ T cells as part of the immune system's surveillance of bodily tissues for foreign and pathogenic material. Antigen processing and presentation pathways have been characterized in detail in normal cells, but there is little known about the actual viral peptides that are presented to CD4+ T cells that signal infection. In this study, two-dimensional LC-MS/MS was used to identify vaccinia virus-derived peptides among the hundreds to thousands of peptide antigens bound to the human class II MHC protein HLADR1 on the surface of vaccinia virus-infected cells. The peptides, derived from the I6L, D6R, and A10L viral proteins, were 15 residues in length, bound efficiently to HLA-DR1 as synthetic peptides, and were recognized by vaccinia-specific $\mathrm{CD} 4^{+} \mathrm{T}$ cells obtained from an immunized donor.
\end{abstract}

\section{Keywords}

tandem mass spectrometry; vaccinia virus; epitope; antigen processing; antigen presentation; peptide binding; $\mathrm{T}$ cell response; $\mathrm{CD}^{+}{ }^{+} \mathrm{T}$-cell; immune response; vaccine

\section{INTRODUCTION}

The eradication of smallpox in 1980 is considered to be one of the most important achievements in public health. Although variola virus, the causative agent of smallpox, is found only in a few high security laboratories at the present time, the possible development of variola as a bioweapon 1,2 and the emergence of related viruses such as monkeypox 3 have renewed interest in immunization against smallpox and other poxvirus infections. Central to the success of the eradication campaign was the use of vaccinia virus as a vaccine for this disease. However serious side effects with the current vaccine limit its use as a preventive tool 4. Identification of vaccinia-derived epitopes presented by MHC molecules to virus-specific $\mathrm{T}$ cells capable of generating immune responses comparable to those

\footnotetext{
* Corresponding author: lawrence.stern@umassmed.edu.
} 
elicited by the attenuated virus but without severe side effects is a major goal in the development of a new generation of safer smallpox vaccines. For poxvirus such as smallpox and vaccinia, $\mathrm{CD}^{+} \mathrm{T}$ cell epitopes, which are presented by class II MHC proteins, are of particular interest because of their role in development of protective antibody responses induced by vaccination 5 .

Only recently have $\mathrm{CD} 4^{+} \mathrm{T}$ cell epitopes been identified for vaccinia virus $6^{-} 10$. Classically, T-cell epitopes are defined by screening of sets of partially overlapping synthetic peptides covering the entire sequence of known antigenic proteins, or covering the entire protein component of a genome if no protein antigens are known. Candidate epitopes are tested for immunogenicity using blood samples from immunized or exposed donors. For a largegenome virus like vaccinia, which encodes over 230 open reading frames, such screening is extremely labor-intensive and requires large numbers of synthetic peptides and blood samples. Recent approaches to identification of $\mathrm{CD} 4^{+} \mathrm{T}$-cell epitopes from vaccinia have emphasized development of high-throughput screening methodology 7,9 and computational prediction of MHC binding affinity 8, 10 to winnow the number of candidate peptides prior to screening. In all of these studies $\mathrm{T}$ cells were used to distinguish epitope from non-epitope sequences. This limits the identification of $\mathrm{T}$ cell epitopes to those detected by the particular $\mathrm{T}$ cell lines used, for which the specificity is dictated by the method used to elicit the line and individual-to-individual differences in immune responses. In addition, impaired antigen presentation in vaccinia infected cells has been reported 11, 12 and appears to be at the level of peptide loading into MHC class II molecules. Direct characterization of peptides bound to class II MHC molecules in infected cells provides information about vaccinia $\mathrm{T}$ cell epitopes complementary to that obtained from cellular studies, and could provide insights into vaccinia effects on antigen presenting pathways.

Mass spectometry has proven effective in the identification of endogenous "self"-peptides presented by a normal uninfected cell $13^{-} 16$, and the spectrum of naturally processed self peptides has been characterized for many MHC II proteins (for examples, see entries in the Syfpeithi (www.syfpeithi.de) 17 and IEDB (www.immunepitope.org) 18 databases). Peptides derived from viral proteins are expected to be present at low abundance among the total pool of MHC-bound peptides, but recent advances in mass spectrometry instrumentation and associated computational methods have allowed extension of these techniques to characterization of peptide antigens derived from infectious agents. The combination of reverse phase liquid chromatography, $\mathrm{T}$ cell screening of chromatographic fractions, and tandem mass spectrometry has been used to characterize several naturally processed MHC class I-restricted $\mathrm{CD}^{+} \mathrm{T}$ cell epitopes, derived from hepatitis B virus 19 , Epstein-Barr virus, 20, 21 and Borna disease virus, one of the few experimental infectious models in rats 22. Far fewer naturally-processed pathogen-derived epitopes have been characterized for MHC class II proteins 23. Two groups have identified MHC class II-bound peptides derived from the transforming viruses used to immortalize the cell lines under study, Epstein-Barr virus 24, 25 and chicken syncytial virus 26 but it is not known whether such peptides are recognized by pathogen-specific T cells. The Mayo Vaccine Research Group has reported an increasing number of HLA-DR3-restricted T cell epitopes originating from measles virus $27^{-2}$. Finally, four HLA-DR1-associated peptide epitopes originating from Neisseria meningitides bacteria have been identified using a stable isotope tagging approach 30. In this work, we report identification by liquid chromatography and tandem mass spectrometry of three naturally-processed $\mathrm{CD} 4^{+} \mathrm{T}$-cell epitopes derived from vaccinia virus. The peptides were sequenced directly after elution from DR1 isolated from infected cells, without the need for pre-screening chromatographic fractions using $\mathrm{T}$ cell lines. Each of the identified peptides binds to DR1, and was recognized by $\mathrm{CD} 4^{+} \mathrm{T}$ cells from a vaccinated donor. 


\section{EXPERIMENTAL PROCEDURES}

\section{Vaccinia Virus (MVA) Infection of B Cells}

The MVA strain of vaccinia virus 31, 32 and an established DR1+ human B lymphoblastoid cell line (LG2, IMGT entry HC10984 33) were used in this study. Cells were infected with live vaccinia virus at a multiplicity of infection (MOI) of approximately 1 and incubated at $37^{\circ} \mathrm{C}$ and $5 \% \mathrm{CO}_{2}$. Uninfected (control) and vaccinia-infected cells were harvested at various times post-infection $(1-22 \mathrm{hrs})$. Equal-sized batches $\left(1 \times 10^{9}\right)$ cells were collected by centrifugation $(1500 \mathrm{~g}, \mathrm{RT}, 10 \mathrm{~min})$, washed in phosphate-buffered saline, and used for isolation of HLA-DR1 molecules and HLA-DR1 - bound peptides as described below.

\section{Determination of fraction of LG2 cell culture infected with vaccinia virus}

The fraction of LG2 cells infected with vaccinia virus was determined by Flow cytometry using purified anti-E3L monoclonal antibody (Tw2.3), a gift of J.W. Yewdell (National Institute of Allergy and Infectious Diseases, Bethesda, MD). The vaccinia E3L protein is a late viral protein that can be detected in infected cells after fixation and permeabilization 34 . At each time point a small aliquot of cells was treated with Cytofix/cytoperm solutions (BD Biosciences), as described by the manufacturer, and divided into fractions for staining with $10 \mu \mathrm{g} / \mathrm{ml}$ of anti-E3L monoclonal antibody (TW2.3), anti-DR1 monoclonal antibody (LB3.1), or an isotype-matched control antibody. Following incubation on ice for $40 \mathrm{~min}$, unbound antibody was removed by three washes with cytoperm buffer. Cell fractions were then incubated with anti-mouse $\operatorname{IgG}(\mathrm{H}+\mathrm{L})$-FITC labeled (Jackson ImmunoResearch) in cytoperm buffer. After washing with cytoperm, cells were fixed with $1 \%$ paraformaldehyde in PBS and loaded into a FACSCalibur instrument (BDBiosciences) equipped with CellQuest Sofware. The obtained dataset was analyzed with FlowJo7.2 (Tree Start Inc).

\section{Isolation of HLA-DR1}

The procedure used for isolation of detergent-solubilized MHC class II proteins from human B cell lines was modified from the one originally described by Gorga et al 35 . Immunoaffinity columns were constructed using protein A-Sepharose (Repligen Corporation, Needham, MA) covalently coupled to a purified HLA-DR1-specific mAb (LB3.1, IgG2b). Briefly, anti-HLA-DR1 $\mathrm{mAb}(2 \mathrm{mg} / \mathrm{ml})$ was added to $5 \mathrm{ml}$ of protein ASepharose beads and mixed by rocking for $1 \mathrm{~h}$. Following incubation, the beads were washed with $200 \mathrm{mM}$ sodium borate ( $\mathrm{pH} \mathrm{9.0)}$ and resuspended in $10 \mathrm{ml}$ of borate buffer containing $400 \mathrm{mM}$ freshly-dissolved dimethyl pimelimidate dihydrochloride (DMP). The coupling reaction was allowed to proceed for 30 minutes, followed by sequential washing with (i) $200 \mathrm{mM}$ ethanolamine ( $\mathrm{pH} 8.0$ ), (ii) $200 \mathrm{mM}$ borate (pH 9.0), (iii) phosphatebuffered saline (PBS) with $0.02 \%$ sodium azide (PBSZ), and finally (iv) 50mM CAPS, (pH 11.5) before equilibration and storage in PBSZ.

Uninfected and vaccinia-infected B cells $\left(10^{9} /\right.$ preparation) were resuspended in $10 \mathrm{ml}$ of icecold lysis buffer $(50 \mathrm{mM}$ Tris- $\mathrm{HCl}, 150 \mathrm{mM} \mathrm{NaCl}, \mathrm{pH} 8.0)$ containing "complete" protease inhibitor tablets (Roche Diagnostics GmbH, Mannheim, Germany). The cells were lysed using a polytron homogenizer, and the mixture was centrifuged at $6,000 \mathrm{~g}, 4^{\circ} \mathrm{C}$ for $10 \mathrm{~min}$ to remove unlysed cells, nuclei and cell debris. The supernatant was reserved and the pellet was resuspended, homogenized, and centrifuged again. This procedure was repeated until the lysate was no longer turbid. The combined supernatants were spun at $75,000 \mathrm{~g}$ for $1 \mathrm{~h}$ at $4^{\circ} \mathrm{C}$ to pellet the membrane fractions. Pelleted membranes were solubilized in $25 \mathrm{ml}$ of icecold lysis buffer containing 5\% $\beta$-octylglucoside (Sigma-Aldrich Corp., St. Louis, MO) and mixed slowly overnight to promote solubilization. After centrifugation of the solubilized membranes at 75,000g for an additional hour, the MHC-class II peptide complexes were isolated by immunoaffinity chromatography using HLA-DR1-specific mAb (LB3.1) coupled 
to protein A-Sepharose. Briefly, a chain of affinity columns (uncoupled Protein A sepharose, human IgG-Protein A sepharose, HLA-A2-specific BB7.2-Protein A sepharose and HLADR1-specific LB3.1-Protein A sepharose) were washed with PBS and equilibrated in lysis buffer, the sample was loaded, and the columns were washed with 5 column volumes of lysis buffer containing $5 \% \beta$-octylglucoside and 10 column volumes of lysis buffer containing $1 \% \beta$-octylglucoside. The columns were separated, and HLA- DR1 molecules were eluted from LB3.1-Protein A Sepharose with 5 column volumes of 50mM CAPS (pH 11.5). Eluates were immediately neutralized with $300 \mathrm{mM} \mathrm{NaH}_{2} \mathrm{PO}_{4}(\mathrm{pH} 6.0)$, and concentrated by ultrafiltration (Amicon Ultracel-10 membrane, Millipore, Billerica, MA) approximately 20 fold. Buffer exchange, to PBS, was performed to remove any remaining detergent.

HLA-DR1, pre-loaded with influenza hemagglutinin (HA) fragment 306-318 (PKYVKQNTLKLAT), was used as an internal standard $(1 \mu \mathrm{g})$ corresponding to $\sim 1 \%$ of the total amount of HLA-DR1 level, of purified recombinant HLA-DR1 in complex with HA peptide was added to the infected and control sample lysates before immunoaffinity purification.

\section{Peptide Elution}

Peptides were released by acid elution following a procedure originally developed by Demotz et al 36. Acetic acid (14\% final concentration) was added to immunoaffinitypurified HLA-DR 1 to dissociate any bound peptides. The mixture, in a total volume of $2 \mathrm{ml}$, was incubated at $65^{\circ} \mathrm{C}$ for $10 \mathrm{~min}$ to promote full peptide dissociation. Released peptides were concentrated by another ultrafiltration step (Centricon YM-10 membrane, Millipore, Billerica, MA), and were further vacuum-concentrated in a Speed-Vac (Savant Industries) before storage at $-20^{\circ} \mathrm{C}$.

\section{Peptides Desalting and Fractionation}

HLA class II-eluted peptides were desalted and fractionated into 12 fractions per sample using a $1 \mathrm{~mm}$ i.d. (inner diameter) by $10 \mathrm{~mm}$ long reversed phase cartridge (Peptide Micro Trap; Michrom BioResources, Inc., Auburn, CA). The solvent system was composed of $0.01 \%$ trifluoroacetic acid in water (A) and $0.01 \%$ trifluoroacetic acid in acetonitrile (B). The sample was introduced into the column for 15 min using solvent $\mathrm{A}$, after that flow was reversed and the cartridge was washed with $2 \% \mathrm{~B}$ in A for 5 minutes. Then the gradient of $2-60 \% \mathrm{~B}$ in $30 \mathrm{~min}, 60-100 \% \mathrm{~B}$ in $15 \mathrm{~min}$ at flow rate $0.2 \mathrm{ml} / \mathrm{min}$ was programmed. The gradient was followed by 10 minutes wash using solvent B only. The collected fractions ( 5 minutes, $1 \mathrm{ml}$ each; 12 per sample) were vacuum-concentrated to a final volume of $\sim 10 \mu \mathrm{l}$.

\section{Microcapillary Liquid Chromatography Tandem Mass Spectrometry ( $\mu$ LC-MS/MS)}

The eluted peptide fractions were diluted with acetonitrile/formic acid to produce final concentrations of $2 \%$ acetonitrile and $2 \%$ formic acid and were analyzed by microcapillary LC-MS/MS using a Finnigan LTQ linear quadrupole ion trap mass spectrometry system (ThermoFisher, MA). Peptides were first trapped on a $300 \mu \mathrm{m}$ i.d. $\times 5 \mathrm{~mm}, 5 \mu \mathrm{m}, 100 \AA$ C-18 PepMap column (LC Packings, CA) at a flow rate of $35 \mu \mathrm{l} / \mathrm{min}$ in $2 \%$ acetonitrile, $0.1 \%$ formic acid. The flow through the trapping column was then reversed and reduced to $350 \mathrm{nl} / \mathrm{min}$ and directed onto the $75 \mu \mathrm{m}$ i.d. $\times 100 \mathrm{~mm}$ PicoFrit capillary column (New Objective, MA). The solvent system was composed of $0.1 \%$ formic acid, $0.01 \%$ trifluoroacetic acid in $2 \%$ acetonitrile (A) and $0.1 \%$ formic, $0.01 \%$ trifluoroacetic acid in $90 \%$ acetonitrile (B). The elution gradient was programmed as follows: $2 \%$ B for 4 min, $2-17 \%$ B in $8 \mathrm{~min}, 17-40 \% \mathrm{~B}$ in $18 \mathrm{~min}$, and $40-98 \% \mathrm{~B}$ in $4 \mathrm{~min}$. The LTQ mass spectrometer was operated in data dependent mode with one full survey scan $(\mathrm{m} / \mathrm{z}$ 400-2000), followed by product ion scans (relative CID energy 35) of 10 the most intense 
ions in the survey scan. The product ion scans were acquired with a 2.0 unit isolation width and normalized collision energy of 35.0. Ions selected for product ion scans were placed on an exclusion list for the following $30 \mathrm{sec}$. Sample ion spectra are shown in Supplemental Figure 1.

\section{Peptide Identification}

The product ion acquired spectra were searched against the combined human and vaccinia virus strain MVA subsets of the NCBI nr database (July 2006 release) using the SEQUEST (ThermoFinnigan, San Jose, CA; version 27, rev. 12) search engine. Search parameters were set as follows: precursor ion mass tolerance $\pm 1.5 \mathrm{Da}$, fragment ion mass tolerance $\pm 0.5 \mathrm{Da}$, no enzyme specificity, monoisotopic precursor mass, monoisotopic fragment ion mass, variable modification of methionine oxidation. Search results were imported into the Scaffold program (version Scaffold-01_06_06, Proteome Software Inc., Portland, OR) for subsequent X!Tandem (www.thegpm.org; version 2006.04.01.2) searching and probabilistic evaluation of search results. Search results were filtered using Sequest based thresholds at HUPO recommended confidence settings $37\left(\Delta \mathrm{C}_{\mathrm{n}}>0.1\right.$; XCorr: $1+>1.5,2+>2.3,3+>2.5$; $\mathrm{Sp} \geq 300$ ) with a Scaffold peptide probability $>80 \%$ and protein probability $>50 \%$. An additional search was carried out using these same parameters but instead performed against a database containing both forward and reverse human and vaccinia sequences. Of the 102 ions from the infected cell sample for which sequence identification could be made, only one $(\mathrm{m} / z=908.76)$ scored above these filter settings in a reverse database search. All vaccinia sequences identified were confirmed by comparison of the product ion spectra from the eluted samples and the product ion spectra obtained from the synthetic peptides.

\section{Peptide Synthesis}

Peptides I6L[338-352] sequence IYTYRIIKSSFPVPT, D6R[157-171] sequence KIPFLLLSGSPITNT, and A10L[293-307] sequence SMRYQSLIPRLVEFF from vaccinia virus, and the control Gag peptide from HIV Gag protein p24[33-44] sequence PEVIPMFSALSEGATP38 and HA[306-318] peptide PKYVKQNTLKLAT were synthesized using standard solid-phase Fmoc chemistry on a Symphony (Protein Technology Inc., Tucson, AZ) peptide synthesizer and purified by HPLC (Vydac-C18). The purity and homogeneity of each peptide was checked by high performance liquid chromatography and MALDI-TOF mass spectrometry.

\section{Peptide Binding Assay}

For peptide binding experiments, recombinant HLA-DR1 protein was produced by expression of the extracellular domains of its $\alpha$ and $\beta$ subunits in Escherichia coli, followed by isolation of inclusion bodies and refolding in vitro as described previously 39 . Refolded HLA-DR1 was purified by immunoaffinity chromatography using the conformation-specific monoclonal antibody LB3.1, followed by gel filtration chromatography in phosphatebuffered saline, $\mathrm{pH}$ 6.8. The protein concentration was measured by UV absorbance at 280 $\mathrm{nm}$, using $\varepsilon_{280}$ of $54375 \mathrm{M}^{-1} \mathrm{~cm}^{-1}$. A competition binding assay was used to determine the binding affinities of the synthetic peptides to HLA-DR1. Peptide-free HLA-DR1 (15nM) was mixed together with biotinylated influenza hemagglutinin HA[306-318] peptide probe $\left(\mathrm{Ha}_{\mathrm{bio}}, 15 \mathrm{nM}\right)$ and varying concentrations of unlabelled competitor peptide $\left(10^{-10}-10^{-5}\right.$ M). The mixtures were incubated for 3 days at $37^{\circ} \mathrm{C}$ in $100 \mathrm{mM}$ sodium phosphate buffer at pH 5.5 , containing protease inhibitors and $0.5 \mathrm{mg} / \mathrm{ml} \beta$-octylglucoside, followed by detection of bound biotinylated peptide using an immunoassay that employs anti-DR1 capture antibody LB3.1 and alkaline phosphatase-labeled streptavidin. $\mathrm{IC}_{50}$ values were obtained by fitting a binding curve to the plots of absorbance versus concentration of competitor peptide. 


\section{T Cell Lines}

The generation and characterization of vaccinia $\mathrm{T}$ cell lines (TCLs) used in this study have been described 10. Briefly, blood samples were obtained from a DR1 donor using sodium heparin as anticoagulant. This donor was immunized approximately 35 years before the first sample of blood was obtained. A second blood sample was obtained 13 days after reimmunization (2nd dose of the vaccine). Peripheral blood lymphocytes (PBMCs) were purified from blood samples by standard techniques using Ficoll-Hypaque (Pharmacia). After washing with PBS, cells were resuspended in cRPMI+10\%HS (RPMI supplemented with $10 \%$ heat inactivated human $\mathrm{AB}+$ serum, L-glutamine, penicillin streptomycin, nonessential amino acids, and sodium pyruvate) and adjusted to concentration of $2 \mathrm{million} / \mathrm{ml}$. One million cells were then added per well into a 24 well tissue culture plate and volume adjusted to $1 \mathrm{ml}$ by addition of antigen. In the case of anti-vaccinia TCLs, we used a cell extract of CV-1 cells infected with the Dryvax strain of vaccinia virus as antigen. Vaccinia virus in the extract was inactivated by incubation at $60^{\circ} \mathrm{C}$ for $1 \mathrm{hr}$ and concentration adjusted to $1.7 \times 10^{7} \mathrm{pfu} / \mathrm{ml}$ by dilution in cRPMI+10\% HS. After three days of antigenic stimulation, $1 \mathrm{ml}$ of cRPMI+10\% HS supplemented with $100 \mathrm{U} / \mathrm{ml} \mathrm{IL}-2$ were added per well. During the following 12 days, cells were fed with medium supplemented with IL-2 every three to four days. TCLs to peptide A10L were generated as described above from the same vacciniaimmunized donor and from a non-immunized donor using $10 \mu \mathrm{M}$ of peptide instead of vaccinia virus for the in vitro expansion.

\section{ELISPOT Assay}

$\mathrm{T}$ cell responses were evaluated by IFN- $\gamma$ ELISPOT according to the protocol described by the manufacturer (BD Biosciences). Briefly, ELISPOT plates were coated overnight with anti-human IFN- $\gamma$ antibody and the following day washed three times with PBS and blocked with cRPMI $+10 \%$ HS for two hours. As antigen presenting cells, we used either (a) MVAinfected-LG2 B cells fixed for 10 min on ice with $1 \%$ paraformaldehyde in PBS, washed twice with PBS and once with cRPMI $+10 \% \mathrm{HS}$, or (b) autologous PBMCs that were irradiated before use (4800 rads). LG2 cells were used at $5 \times 10^{4}$ cells/well and PBMCs at $1 \times 10^{5}$ cells/well. Synthetic peptides served as antigen in assays using PBMCs. T cells were added after washing twice in PBS and once in cRPMI $+10 \%$ HS. Fifty thousand T cells were added per well. ELISPOT plates were incubated for either 1 to 22 hours, when infected LG2 cells were used as APCs, or overnight (15 to 17 hours), when irradiated PBMCs were used as APCs. Following incubation, the plates were washed, incubated sequentially with biotinylated anti-IFN- $\gamma$, avidin-peroxidase, and finally in AEC substrate. The number of IFN- $\gamma$-secreting cells was determined using an ELISPOT analyzer equipped with ImmunoSpot 3.2 software (Cellular Technology Ltd, Cleveland, Ohio).

\section{RESULTS AND DISCUSSION}

\section{Isolation of naturally processed peptides from non-infected and vaccinia virus-infected B cells}

In order to increase the likelihood of isolating MHC-vaccinia peptide complexes among the pool of endogenous peptide complexes, we infected HLA-DR1 (DRB1*0101)-positive Blymphoblastoid cell line LG2 with the attenuated vaccinia virus strain MVA (modified vaccinia Ankara) and followed the kinetics of the T-cell response from 1 to 22 hours post infection. We reasoned that $\mathrm{T}$ cell responses to virus-infected cells would correlate with the number or quantity of vaccinia peptides bound to MHC molecules. In this manner, T cells will be used as an indicator of antigen processing and presentation (Figure 1A).

Lymphoblastoid cell lines, similar to the one we used in this study, are frequently used to study class II-restricted responses. 
We found that $\mathrm{T}$ cell responses, measured as the number of IFN- $\gamma$ secreting cells in an ELISPOT assay, increased over time with the maximum response at 22 hours, the last time point analyzed. To measure the fraction of cells infected under these conditions, we used flow cytometry to detect expression of the late vaccinia protein E3L in samples of permeabilized cells. Approximately 50\% of the cells expressed vaccinia proteins at 22 hours post-infection (Figure 1B). Infected cells harvested at this time were used for isolation of MHC proteins and characterization of MHC-bound peptides. HLA-DR1 was isolated from infected and control non-infected LG2 cells by immunoaffinity chromatography of detergent-solubilized membrane fractions, following a conventional protocol 35 (see Methods for details). Approximately $0.6 \mathrm{mg}$ of DR1 was recovered from 1 liter culture medium containing $10^{9}$ cells. No significant difference in yield of HLA-DR1 was observed between the infected and control samples (not shown). Peptides were eluted under acid conditions as described 13, 40 and vacuum concentrated for further analysis.

\section{Identification of peptide sequences}

The eluted peptides were desalted and fractioned into a total of 12 fractions per sample using an off-line Peptide Micro Trap reverse-phase HPLC trapping column (Michrom BioResources, Inc., Auburn, CA). Each fraction was analyzed separately by $\mu \mathrm{LC}-\mathrm{MS} / \mathrm{MS}$ (LTQ, ThermoFinnigan) and the resulting MS/MS spectra were searched for human and vaccinia peptides using the SEQUEST search engine (ThermoFisher). The spectra were searched against a library containing the NCBI non-redundant (nr) human database and all vaccinia (MVA) sequences, using Sequest XCorr-based thresholds at HUPO recommended filter settings $\left(\Delta \mathrm{C}_{\mathrm{n}}>0.1 ; 1+>1.5,2+>2.3,3+>2.5\right)$ with $\mathrm{Sp} \geq 300$ and Scaffold peptide probability at $80 \%$ or higher. These filter settings allowed for identification of an internal control peptide (influenza hemagglutinin (HA) fragment 306-318 PKYVKQNTLKLAT) in both infected and non-infected samples, while at the same time eliminated all vacciniaderived false-positive sequences identified in non-infected sample. The internal standard was introduced in the form of purified HLA-DR1-HA peptide complexes at approximately $1 \%$ abundance to the mixture of MHC-peptide complexes purified from infected and control cells. The HA peptide sequence was identified by a SEQUEST search within Peptide Micro Trap fraction 9 (from both infected and control cells) with $\mathrm{m} / \mathrm{z} 753.3$ (+2) (data not shown).

One potential complication in the use of database-driven sequence identification rather than complete de novo sequencing based on fragmentation analysis is the possibility of misidentification of peptides due to statistical matching of incomplete fragmentation patterns 41 . One proposed solution to this problem is the inclusion of randomized sequences in the database that can be used to evaluate the statistical frequency of such mismatches 42 . A reverse database analysis of a subset of 102 peptide ions identified in fractions from the infected cells, only one was identified in a reverse database search using the same parameters, suggesting an approximate false-positive rate of $\sim 1 \%$. Overall, 165 individual DR1-bound peptides derived from 106 different human proteins were identified in fractions from the infected and non-infected control cells (see Supplement Table 1 and 2). In many cases, a particular peptide sequence was represented by several partially overlapping peptides in nested sets, as previously observed for naturally processed peptides bound to MHC class II proteins 13,16, 43, a result of the differential processing of peptide termini extending out the ends of the MHC peptide class II binding groove. Peptide sequences derived from the MHC class II-associated invariant chain, the MHC class I protein HLA-A2, and the transferrin receptor have been observed previously in studies of endogenous peptides bound to HLA-DR1 isolated from B cell lines 13, 44. Sequences derived from annexin A2, MHC class II DR alpha, protective protein for beta-galactosidase, eukaryotic translation elongation factor 1, phosphoglycerate kinase, and cathepsin $\mathrm{S}$ have been observed previously in a study of endogenous peptides presented by DR1/DR12 
heterozygous dendritic cells 45 . The other sequences likely represent new endogenous peptide sequences. Most of the peptide sequences derived from human proteins were observed in both infected and control cells, but 44 peptides were observed only in the control cells, and 39 only in the infected cells. No significant differences in length, net charge, or average Kyte-Doolittle hydrophobicity values 46 were observed between the sets of peptides eluted from infected or control cells.

\section{Naturally processed vaccinia-derived peptides}

The SEQUEST search identified three peptides with sequences originating from vaccinia virus proteins (Table 1), present in the vaccinia-infected but not in non-infected cells that provided a control for false identification.

These vaccinia-derived peptides had SEQUEST XCorr scores significantly higher than the top match of the peptides eluted from non-infected cells, which could be considered as a relevant background level. These peptides originate from three different proteins: the telomere binding protein I6L (MVA067L), the early transcription factor VETF-1 aka D6R (MVA103R), and the major core protein A10L, precursor $\mathrm{p} 4 \mathrm{a}$ of core protein $4 \mathrm{a}$, (MVA121L). The first of these sequences is derived from the vaccinia virus telomere binding protein I6L and was found in Peptide Micro Trap fraction 5.

Figure 2A shows the CID product ion spectrum from precursor ion of $m / z 892.93(+2)$ that has been identified as IYTYRIIKSSFPVPT from vaccinia virus protein I6L (NCBI accession number gi|47088395) residues 338-352. To verify the identification of the $\mathrm{m} / \mathrm{z}$ $892.93(+2)$ as IYTYRIIKSSFPVPT, this sequence was chemically synthesized, purified, and subjected to the same MS/MS fragmentation (see Figure $2 \mathrm{~B}$ ). The naturally processed peptide obtained from the $\mathrm{m} / z 892.93$ and the synthetic peptide IYTYRIIKSSFPVPT demonstrated an essentially identical product ion spectrum, clearly confirming the validity of the identification. The I6L residue 338-352 sequence identified here is highly conserved among poxvirus family members and within different vaccinia strains (see Table 2).

The second vaccinia virus derived peptide was found in fraction 8 . The product ion spectrum (Figure 3A) obtained for a precursor ion $\mathrm{m} / \mathrm{z} 801.10(+2)$ has been identified as KIPFLLLSGSPITNT from the vaccinia virus early gene transcription factor (D6R or VETF-1; NCBI accession number gi|47088431) residues 157-171. A BLAST search done for this sequence shows that the identified peptide is highly conserved across number of other poxviruses as well as within vaccinia virus strains (Table 2).

MS/MS fragmentation pattern of synthetic KIPFLLLSGSPITNT peptide (Figure 3B) matches the spectrum of the naturally processed material confirming positive identification.

The third vaccinia peptide was found in fraction 9. Its precursor ion was $m / z .944 .00(+2)$ and it was identified as SMRYQSLIPRLVEFF from vaccinia virus major core protein 4a (A10L; NCBI accession number gi|47088449) residues 293-307 (Figure 4A). The identified fragment appears to be conserved among poxvirus family members (see Table 2). In addition, the naturally processed peptide and the synthetic peptide SMRYQSLIPRLVEFF peptide exhibit nearly identical product ion spectra confirming the validity of the identification (Fig 4B).

Comparison of integrated peak intensities of the three vaccinia-derived peptides and the internal HA control peptide in experimental samples and in synthetic peptide mixtures suggests that the A10L and I6L peptides were present at $\sim 1 \%$ or less of the total DR1-bound peptide pool, with the D10R peptide present at a substantially lower abundance. Additional 
viral peptides bound to DR1 on the surface of vaccinia-infected B cells might be present but below our level of detection.

Each of these peptides are encoded by a gene with a promoter sequence characteristic of late gene expression $47^{-} 49$, and each is a component of the infectious viral particle 50. None of the proteins is known to be membrane associated, although I6L has been suggested to be important in encapsidation of the virus 51. How these proteins enter the MHC class II antigen loading process is not clear. It is possible that membrane-associated virions access the endo/lysosomal pathway through conventional endocytosis, or that autophagocytic pathways can access viral factories, the site of intensive vaccinia protein synthesis and viral assembly in infected cells 52 .

Each of the eluted peptides was 15 residues long. In each case, the predicted DR1-binding 9mer sequence (underlined in Table 2) was flanked by three residues on each side, consistent with the pattern observed for most naturally processed class II MHC antigens. The 15 residue length is somewhat shorter although not significantly different than the median eluted peptide length from either the infected or non-infected cells (18 residues), and within the range observed in a previous study for naturally processed measles peptides 29 .

\section{HLA-DR1 binding activity of eluted peptides}

To evaluate the biological relevance of the naturally processed vaccinia-derived peptides, we characterized their affinity for HLA-DR 1 and their recognition by human $\mathrm{CD} 4^{+} \mathrm{T}$ cells specific for vaccinia virus. The binding affinity of synthetic peptide to HLA-DR1 was studied using a competition ELISA-based assay (see Fig 5). Peptide binding $\mathrm{IC}_{50}$ values were 6.5 to $136 \mathrm{nM}$ (Table 1), within the range of known antigenic peptides, and comparable to the tight-binding immunogenic HA peptide from influenza $\left(\mathrm{IC}_{50}=35 \mathrm{nM}\right)$.

\section{Recognition of the eluted peptide epitopes by antigen-specific T cells}

In order to demonstrate that the vaccinia-derived naturally-processed peptides eluted from infected cells in fact contain epitopes recognized by $\mathrm{CD} 4{ }^{+} \mathrm{T}$ cells, we studied the IFN- $\gamma$ response of T cells from a HLA-DR1 vaccinia-immunized donor to synthetic peptides representing these sequences by ELISPOT. This assay measures the frequency of $\mathrm{T}$ cells that respond to antigenic stimulation by secreting IFN- $\gamma$. As shown in Figure 6A, a vacciniaspecific $\mathrm{T}$ cell line generated many years after a single vaccinia immunization shows a weak response to D6R peptide. Responses to the remaining two peptides are in the same range that the background response. These findings suggest that the response to the D6R peptide is long lived and the corresponding $\mathrm{T}$ cells relatively abundant in this donor.

A second vaccinia immunization would be expected to increase the frequency of responding $\mathrm{T}$ cells, and we subsequently analyzed the response of $\mathrm{T}$ cells obtained 13 days after a booster immunization (figure 6B). We observed an improved response to the I6L peptide, but, somewhat contrary to our expectations, not to the D6R peptide. Thus, a T cell response to the I6L peptide also is induced by vaccination, but the responding cells either are shortlived or present at a lower abundance relative to those directed at the D6R peptide. The lack of recognition of the $\mathrm{A} 10 \mathrm{~L}$ peptide could indicate that $\mathrm{T}$ cells recognizing this peptide are absent, are present at a very low frequency, or do not expand well in vitro using the heatinactivated vaccinia stimulation protocol employed in the generation of vaccinia-specific $\mathrm{T}$ cell lines. To explore these possibilities, we obtained blood from one immunized and one non-immunized DR1+ donors, and generated peptide-specific T cells lines by expansion with peptide $\mathrm{A} 10 \mathrm{~L}$ instead of heat-killed vaccinia virus. The fine specificity of the antipeptide $\mathrm{T}$ cell lines was evaluated as before by IFN- $\gamma$ ELSIPOT in antigen presenting cells pulsed with peptide A10L or a control peptide (Gag peptide). As shown in Figure 6C, 
responses to either Gag or A10L peptides in the T cell line generated from the nonimmunized donor are in the same order of $\mathrm{T}$ cells from wells in which peptide was omitted suggesting a very low frequency of anti-peptide A10L T cells in the non-immunized donor. In contrast, responses to peptide $\mathrm{A} 10 \mathrm{~L}$ in the $\mathrm{T}$ cell line generated from the immunized donor were approximately three times higher than the ones observed in the control peptide or wells without peptide. Thus, the A10L peptide also is recognized by T cells of an immunized donor.

The first vaccinia-derived $\mathrm{CD}^{+} \mathrm{T}$ cell epitopes were reported in 2006 in a study of $\mathrm{CD} 4^{+}$ and $\mathrm{CD} 8^{+} \mathrm{T}$ cell responses to overlapping peptide series covering the A29L, L1R, B5R, and A33R proteins 6 . These proteins induce protective antibodies in animal models. However, the epitopes were not associated with a particular MHC protein. Very recently, four studies have reported identification of MHC-restricted $\mathrm{CD} 4{ }^{+} \mathrm{T}$ cell epitopes in humans $7,8,10$, and mice 9. These epitopes were identified by large-scale screening 7, 9 or bioinformatical 8,10 approaches. In three of these studies $6,7,9$, none of the epitopes identified here were observed. Two of the epitopes identified here, from the D1R and I6L epitopes, were identified in our previous study 10. The A10L epitope described here was not identified in any of the previous cell-based epitope screens, despite being present at relatively high abundance among the pool of DR1-bound peptides. The inability of previous approaches to identify this epitope may relate to differences in antigen processing pathways in infected as compared to non-infected cells, or to aspects of the generation of vaccinia-specific $\mathrm{T}$ cell lines, or to individual differences in anti-vaccinia immune responses. Since this epitope derives from an abundantly expressed viral core protein and the naturally processed MHCbound peptide is present at high levels on the surface of vaccinia-infected cells, it would appear to be an attractive candidate for inclusion in a subunit vaccine.

\section{CONCLUSIONS}

In conclusion, we have directly identified from the pool of endogenous MHC-bound peptides by database analysis three vaccinia-derived peptides naturally processed in infected cells and loaded onto the class II MHC protein HLA-DR1. The findings were additionally validated using synthetic versions of the identified peptide sequences. In each case, the fragmentation spectra of the eluted peptides were essentially identical to those of the corresponding synthetic peptides, confirming their identification. These epitopes, conserved in the poxvirus family, are among the naturally processed and characterized $\mathrm{CD} 4^{+}$vaccinia epitopes, and could find use in the development of next-generation vaccines against smallpox and other poxvirus, and in the evaluation of $\mathrm{T}$ cell immunity induced by vaccine candidates.

\section{Supplementary Material}

Refer to Web version on PubMed Central for supplementary material.

\section{Acknowledgments}

The authors thank Loretta Lee for culture of LG2 cells and J.W. Yewdell for the anti-E3L monoclonal antibody Tw2.3. Core resources supported by the Diabetes Endocrinology Research Center grant DK32520 were used. This work was supported by NIH-U19-057319.

\section{REFERENCES}

1. Lane HC, Montagne JL, Fauci AS. Bioterrorism: a clear and present danger. Nat Med. 2001; 7:1271-1273. [PubMed: 11726956] 
2. Rosenthal SR, Merchlinsky M, Kleppinger C, Goldenthal KL. Developing new smallpox vaccines. Emerg Infect Dis. 2001; 7:920-926. [PubMed: 11747717]

3. Larkin M. Monkeypox spreads as US public-health system plays catch-up. Lancet Infect Dis. 2003; 3:461. [PubMed: 12906012]

4. Lane JM, Ruben FL, Neff JM, Millar JD. Complications of smallpox vaccination, 1968. N Engl J Med. 1969; 281:1201-1208. [PubMed: 4186802]

5. Panchanathan V, Chaudhri G, Karupiah G. Correlates of protective immunity in poxvirus infection: where does antibody stand? Immunol Cell Biol. 2007 In press.

6. Tang J, Murtadha M, Schnell M, Eisenlohr LC, Hooper J, Flomenberg P. Human T-cell responses to vaccinia virus envelope proteins. J Virol. 2006; 80:10010-10020. [PubMed: 17005679]

7. Jing L, Chong TM, Byrd B, McClurkan CL, Huang J, Story BT, Dunkley KM, Aldaz-Carroll L, Eisenberg RJ, Cohen GH, Kwok WW, Sette A, Koelle DM. Dominance and diversity in the primary human CD4 T cell response to replication-competent vaccinia virus. J Immunol. 2007; 178:63746386. [PubMed: 17475867]

8. Mitra-Kaushik S, Cruz J, Stern LJ, Ennis FA, Terajima M. Human cytotoxic CD4+ T cells recognize HLA-DR1-restricted epitopes on vaccinia virus proteins A24R and D1R conserved among poxviruses. J Immunol. 2007; 179:1303-1312. [PubMed: 17617623]

9. Moutaftsi M, Bui HH, Peters B, Sidney J, Salek-Ardakani S, Oseroff C, Pasquetto V, Crotty S, Croft M, Lefkowitz EJ, Grey H, Sette A. Vaccinia Virus-Specific CD4+ T Cell Responses Target a Set of Antigens Largely Distinct from Those Targeted by CD8+ T Cell Responses. J Immunol. 2007; 178:6814-6820. [PubMed: 17513729]

10. Calvo-Calle JM, Strug I, Nastke MD, Baker SP, Stern LJ. Human CD4(+) T Cell Epitopes from Vaccinia Virus Induced by Vaccination or Infection. PLoS Pathog. 2007; 3:1511-1529. [PubMed: 17937498]

11. Li P, Wang N, Zhou D, Yee CS, Chang CH, Brutkiewicz RR, Blum JS. Disruption of MHC class II-restricted antigen presentation by vaccinia virus. J Immunol. 2005; 175:6481-8. [PubMed: 16272302]

12. Yao Y, Li P, Singh P, Thiele AT, Wilkes DS, Renukaradhya GJ, Brutkiewicz RR, Travers JB, Luker GD, Hong SC, Blum JS, Chang CH. Vaccinia virus infection induces dendritic cell maturation but inhibits antigen presentation by MHC class II. Cell Immunol. 2007; 246:92-102. [PubMed: 17678637]

13. Chicz RM, Urban RG, Lane WS, Gorga JC, Stern LJ, Vignali DA, Strominger JL. Predominant naturally processed peptides bound to HLA-DR1 are derived from MHC-related molecules and are heterogeneous in size. Nature. 1992; 358:764-768. [PubMed: 1380674]

14. Engelhard VH. Structure of peptides associated with class I and class II MHC molecules. Annu Rev Immunol. 1994; 12:181-207. [PubMed: 7516668]

15. Hunt DF, Henderson RA, Shabanowitz J, Sakaguchi K, Michel H, Sevilir N, Cox AL, Appella E, Engelhard VH. Characterization of peptides bound to the class I MHC molecule HLA-A2.1 by mass spectrometry. Science. 1992; 255:1261-1263. [PubMed: 1546328]

16. Janeway CA Jr. Mamula MJ, Rudensky A. Rules for peptide presentation by MHC class II molecules. Int Rev Immunol. 1993; 10:301-311. [PubMed: 8294843]

17. Rammensee HG, Friede T, Stevanoviic S. MHC ligands and peptide motifs: first listing. Immunogenetics. 1995; 41:178-228. [PubMed: 7890324]

18. Peters B, Sidney J, Bourne P, Bui HH, Buus S, Doh G, Fleri W, Kronenberg M, Kubo R, Lund O, Nemazee D, Ponomarenko JV, Sathiamurthy M, Schoenberger S, Stewart S, Surko P, Way S, Wilson S, Sette A. The immune epitope database and analysis resource: from vision to blueprint. PLoS Biol. 2005; 3:e91. [PubMed: 15760272]

19. Tsai SL, Chen MH, Yeh CT, Chu CM, Lin AN, Chiou FH, Chang TH, Liaw YF. Purification and characterization of a naturally processed hepatitis B virus peptide recognized by CD8+ cytotoxic T lymphocytes. J Clin Invest. 1996; 97:577-584. [PubMed: 8567982]

20. Crotzer VL, Christian RE, Brooks JM, Shabanowitz J, Settlage RE, Marto JA, White FM, Rickinson AB, Hunt DF, Engelhard VH. Immunodominance among EBV-derived epitopes restricted by HLA-B27 does not correlate with epitope abundance in EBV-transformed Blymphoblastoid cell lines. J Immunol. 2000; 164:6120-6129. [PubMed: 10843661] 
21. Herr W, Ranieri E, Gambotto A, Kierstead LS, Amoscato AA, Gesualdo L, Storkus WJ. Identification of naturally processed and HLA-presented Epstein-Barr virus peptides recognized by CD4(+) or CD8(+) T lymphocytes from human blood. Proc Natl Acad Sci U S A. 1999; 96:12033-12038. [PubMed: 10518571]

22. Planz O, Dumrese T, Hulpusch S, Schirle M, Stevanovic S, Stitz L. A naturally processed rat major histocompatibility complex class I-associated viral peptide as target structure of borna disease virus-specific CD8+ T cells. J Biol Chem. 2001; 276:13689-13694. [PubMed: 11278578]

23. Ovsyannikova IG, Johnson KL, Bergen HR 3rd, Poland GA. Mass spectrometry and peptide-based vaccine development. Clin Pharmacol Ther. 2007; 82:644-52. [PubMed: 17971823]

24. Chicz RM, Lane WS, Robinson RA, Trucco M, Strominger JL, Gorga JC. Self-peptides bound to the type I diabetes associated class II MHC molecules HLA-DQ1 and HLADQ8. Int Immunol. 1994; 6:1639-1649. [PubMed: 7865457]

25. Chicz RM, Urban RG, Gorga JC, Vignali DA, Lane WS, Strominger JL. Specificity and promiscuity among naturally processed peptides bound to HLA-DR alleles. J Exp Med. 1993; 178:27-47. [PubMed: 8315383]

26. Cumberbatch JA, Brewer D, Vidavsky I, Sharif S. Chicken major histocompatibility complex class II molecules of the B haplotype present self and foreign peptides. Anim Genet. 2006; 37:393-396. [PubMed: 16879355]

27. Ovsyannikova IG, Johnson KL, Naylor S, Poland GA. Identification of HLADRB1-bound selfpeptides following measles virus infection. J Immunol Methods. 2005; 297:153-167. [PubMed: 15777939]

28. Johnson KL, Ovsyannikova IG, Poland GA, Muddiman DC. Identification of class II HLADRB $1 * 03$-bound measles virus peptides by $2 \mathrm{D}$-liquid chromatography tandem mass spectrometry. J Proteome Res. 2005; 4:2243-2249. [PubMed: 16335972]

29. Ovsyannikova IG, Johnson KL, Naylor S, Muddiman DC, Poland GA. Naturally processed measles virus peptide eluted from class II HLA-DRB $1 * 03$ recognized by $\mathrm{T}$ lymphocytes from human blood. Virology. 2003; 312:495-506. [PubMed: 12919753]

30. Meiring HD, Kuipers B, van Gaans-van den Brink JA, Poelen MC, Timmermans H, Baart G, Brugghe H, van Schie J, Boog CJ, de Jong AP, van Els CA. Mass tag-assisted identification of naturally processed HLA class II-presented meningococcal peptides recognized by CD4+ T lymphocytes. J Immunol. 2005; 174:5636-5643. [PubMed: 15843563]

31. Mayr A, Stickl H, Muller HK, Danner K, Singer H. [The smallpox vaccination strain MVA: marker, genetic structure, experience gained with the parenteral vaccination and behavior in organisms with a debilitated defence mechanism (author's transl)]. Zentralbl Bakteriol [B]. 1978; 167:375-390.

32. Antoine G, Scheiflinger F, Dorner F, Falkner FG. The complete genomic sequence of the modified vaccinia Ankara strain: comparison with other orthopoxviruses. Virology. 1998; 244:365-396. [PubMed: 9601507]

33. Robinson J, Waller MJ, Parham P, de Groot N, Bontrop R, Kennedy LJ, Stoehr P, Marsh SG. IMGT/HLA and IMGT/MHC: sequence databases for the study of the major histocompatibility complex. Nucleic Acids Res. 2003; 31:311-314. [PubMed: 12520010]

34. Yuwen H, Cox JH, Yewdell JW, Bennink JR, Moss B. Nuclear localization of a double-stranded RNA-binding protein encoded by the vaccinia virus E3L gene. Virology. 1993; 195:732-744. [PubMed: 8337842]

35. Gorga JC, Horejsi V, Johnson DR, Raghupathy R, Strominger JL. Purification and characterization of class II histocompatibility antigens from a homozygous human B cell line. J Biol Chem. 1987; 262:16087-16094. [PubMed: 2824477]

36. Demotz S, Grey HM, Appella E, Sette A. Characterization of a naturally processed MHC class IIrestricted T-cell determinant of hen egg lysozyme. Nature. 1989; 342:682-684. [PubMed: 2480524]

37. Omenn GS, States DJ, Adamski M, Blackwell TW, Menon R, Hermjakob H, Apweiler R, Haab BB, Simpson RJ, Eddes JS, Kapp EA, Moritz RL, Chan DW, Rai AJ, Admon A, Aebersold R, Eng J, Hancock WS, Hefta SA, Meyer H, Paik YK, Yoo JS, Ping P, Pounds J, Adkins J, Qian X, Wang R, Wasinger V, Wu CY, Zhao X, Zeng R, Archakov A, Tsugita A, Beer I, Pandey A, Pisano M, 
Andrews P, Tammen H, Speicher DW, Hanash SM. Overview of the HUPO Plasma Proteome Project: results from the pilot phase with 35 collaborating laboratories and multiple analytical groups, generating a core dataset of 3020 proteins and a publicly-available database. Proteomics. 2005; 5:3226-3245. [PubMed: 16104056]

38. Montavon C, Toure-Kane C, Liegeois F, Mpoudi E, Bourgeois A, Vergne L, Perret JL, Boumah A, Saman E, Mboup S, Delaporte E, Peeters M. Most env and gag subtype A HIV-1 viruses circulating in West and West Central Africa are similar to the prototype AG recombinant virus IBNG. J Acquir Immune Defic Syndr. 2000; 23:363-374. [PubMed: 10866228]

39. Frayser M, Sato AK, Xu L, Stern LJ. Empty and peptide-loaded class II major histocompatibility complex proteins produced by expression in Escherichia coli and folding in vitro. Protein Expr Purif. 1999; 15:105-114. [PubMed: 10024477]

40. van Bleek GM, Nathenson SG. The structure of the antigen-binding groove of major histocompatibility complex class I molecules determines specific selection of self-peptides. Proc Natl Acad Sci U S A. 1991; 88:11032-11036. [PubMed: 1763019]

41. Cargile BJ, Bundy JL, Stephenson JL Jr. Potential for false positive identifications from large databases through tandem mass spectrometry. J Proteome Res. 2004; 3:1082-1085. [PubMed: 15473699]

42. Higdon R, Kolker E. A predictive model for identifying proteins by a single peptide match. Bioinformatics. 2007; 23:277-280. [PubMed: 17121779]

43. Rudensky A, Janeway CA Jr. Studies on naturally processed peptides associated with MHC class II molecules. Chem Immunol. 1993; 57:134-151. [PubMed: 8260086]

44. Verreck FA, van de Poel A, Drijfhout JW, Amons R, Coligan JE, Konig F. Natural peptides isolated from Gly86/Val86-containing variants of HLA-DR1, -DR11, -DR13, and -DR52. Immunogenetics. 1996; 43:392-397. [PubMed: 8606061]

45. Rohn TA, Boes M, Wolters D, Spindeldreher S, Muller B, Langen H, Ploegh H, Vogt AB, Kropshofer H. Upregulation of the CLIP self peptide on mature dendritic cells antagonizes $\mathrm{T}$ helper type 1 polarization. Nat Immunol. 2004; 5:909-918. [PubMed: 15322540]

46. Kyte J, Doolittle RF. A simple method for displaying the hydropathic character of a protein. J Mol Biol. 1982; 157:105-132. [PubMed: 7108955]

47. Jensen ON, Houthaeve T, Shevchenko A, Cudmore S, Ashford T, Mann M, Griffiths G, Krijnse Locker J. Identification of the major membrane and core proteins of vaccinia virus by twodimensional electrophoresis. J Virol. 1996; 70:7485-7497. [PubMed: 8892867]

48. Li J, Pennington MJ, Broyles SS. Temperature-sensitive mutations in the gene encoding the small subunit of the vaccinia virus early transcription factor impair promoter binding, transcription activation, and packaging of multiple virion components. J Virol. 1994; 68:2605-2614. [PubMed: 8139039]

49. DeMasi J, Du S, Lennon D, Traktman P. Vaccinia virus telomeres: interaction with the viral I1, I6, and K4 proteins. J Virol. 2001; 75:10090-10095. [PubMed: 11581377]

50. Resch W, Hixson KK, Moore RJ, Lipton MS, Moss B. Protein composition of the vaccinia virus mature virion. Virology. 2007; 358:233-247. [PubMed: 17005230]

51. Grubisha O, Traktman P. Genetic analysis of the vaccinia virus I6 telomere-binding protein uncovers a key role in genome encapsidation. J Virol. 2003; 77:10929-10942. [PubMed: 14512543]

52. Strawbridge AB, Blum JS. Autophagy in MHC class II antigen processing. Curr Opin Immunol. 2007; 19:87-92. [PubMed: 17129719] 


\section{A}

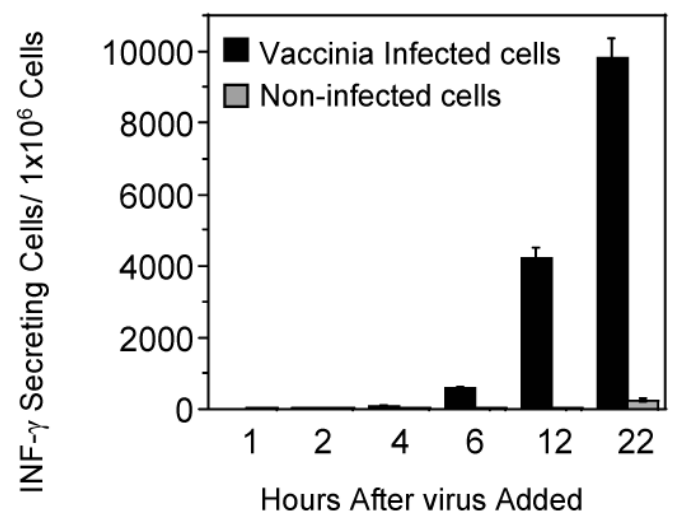

B

Un-Infected LG2 Cells

Vaccinia Infected LG2 Cells
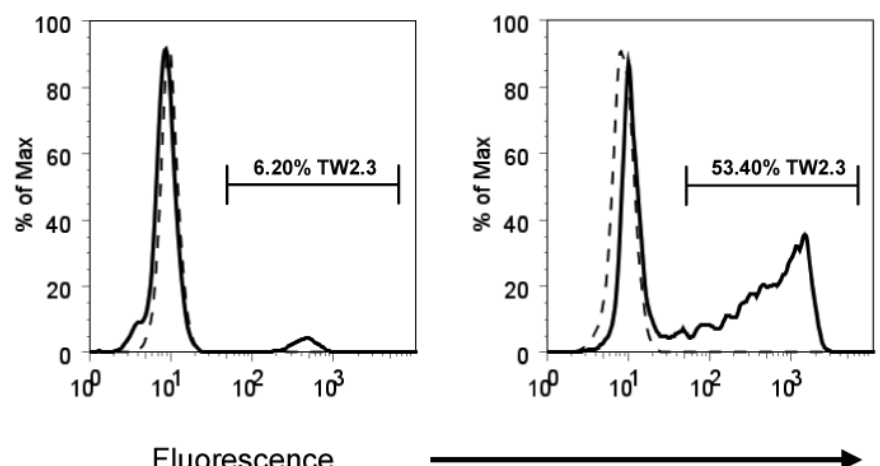

Figure 1. Analysis of LG2 cells infected with the vaccinia virus MVA strain

(A) T cell response against MVA vaccinia infected (solid bars) and non-infected LG2 cells (gray bars), expressed as the number of IFN- $\gamma$ secreting cells activated at various times after the addition of virus. (B) Flow cytometry determination of the number of infected cells using intracellular staining to the vaccinia late protein E3L. Left panel, non-infected cells; right panel, infected cells. Staining with isotype-matched control antibody is presented in dotted lines and staining with anti-E3L (TW2.3) antibody in continuous lines. The percentage of E3L positive cells is indicated in the histograms. 
A
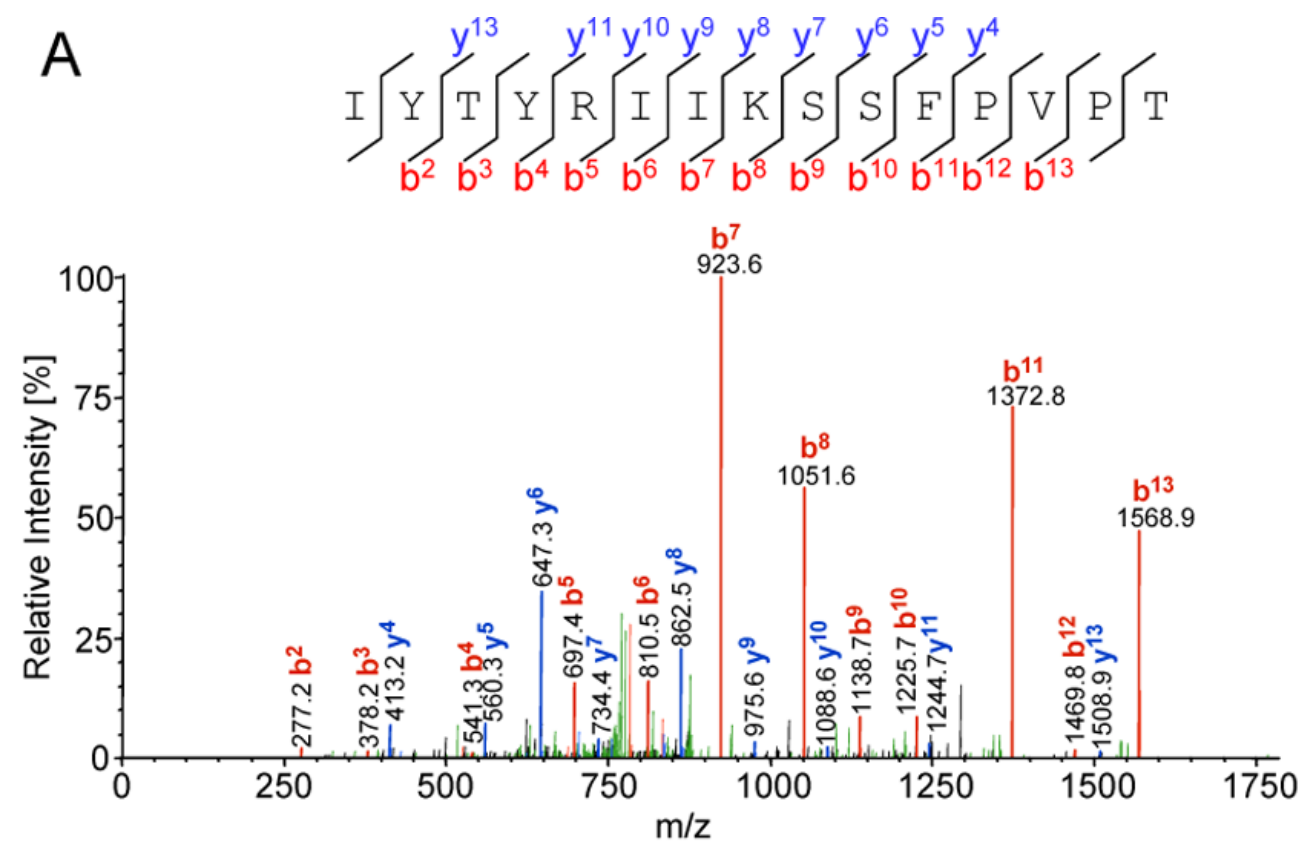

B
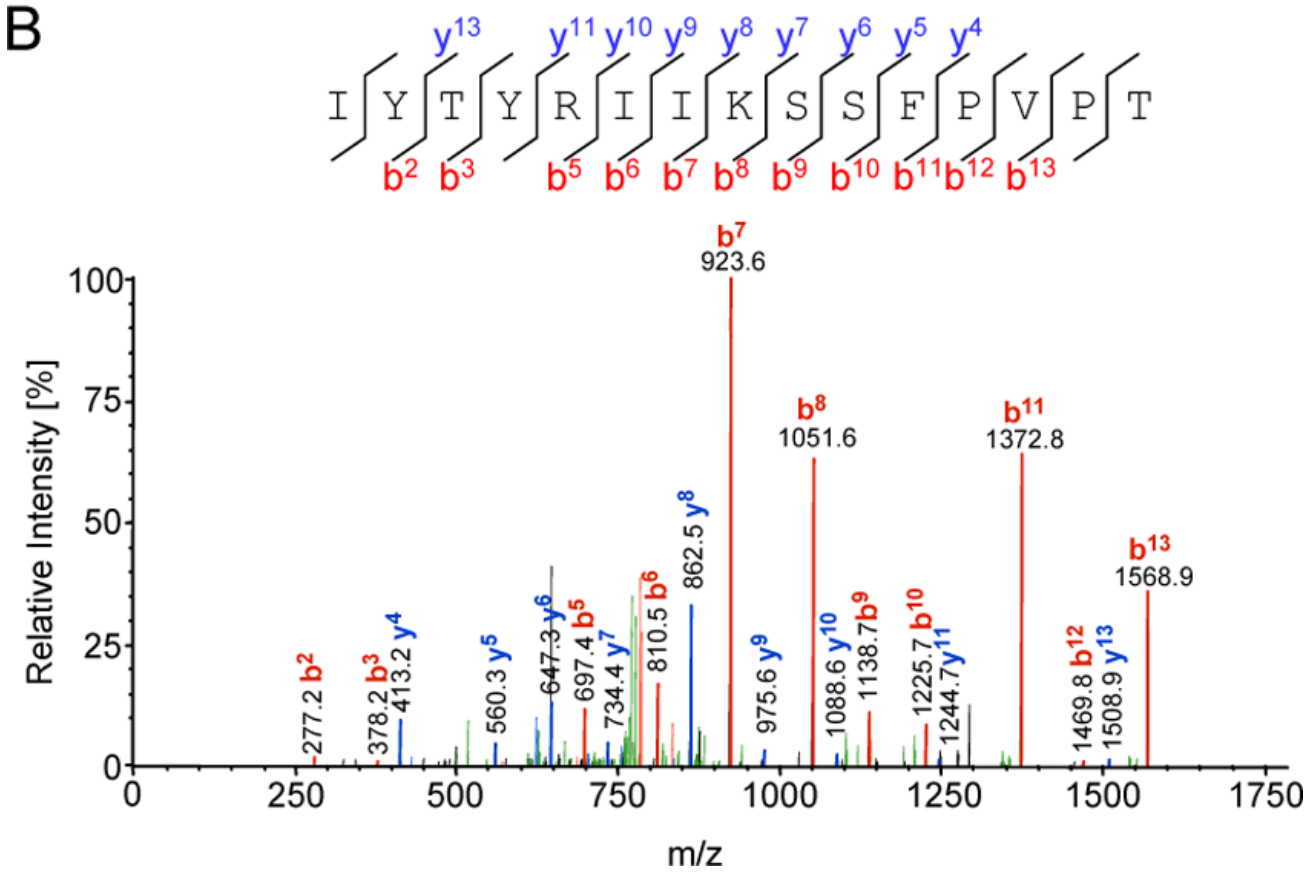

Figure 2. Identification of HLA-DR1 binding peptide originating from vaccinia virus I6L protein (A) MS/MS spectra from naturally processed peptide isolated from vaccinia virus-infected LG2 cells. The candidate ion $\mathrm{m} / \mathrm{z} 892.9$ has been identified, using SEQUEST ${ }^{\mathrm{TM}}$ (Thermo Fisher Scientific), as a fragment of vaccinia virus I6L protein. (B) Corresponding fragmentation patter from the synthetic IYTYRIIKSSFPVPT peptide. 


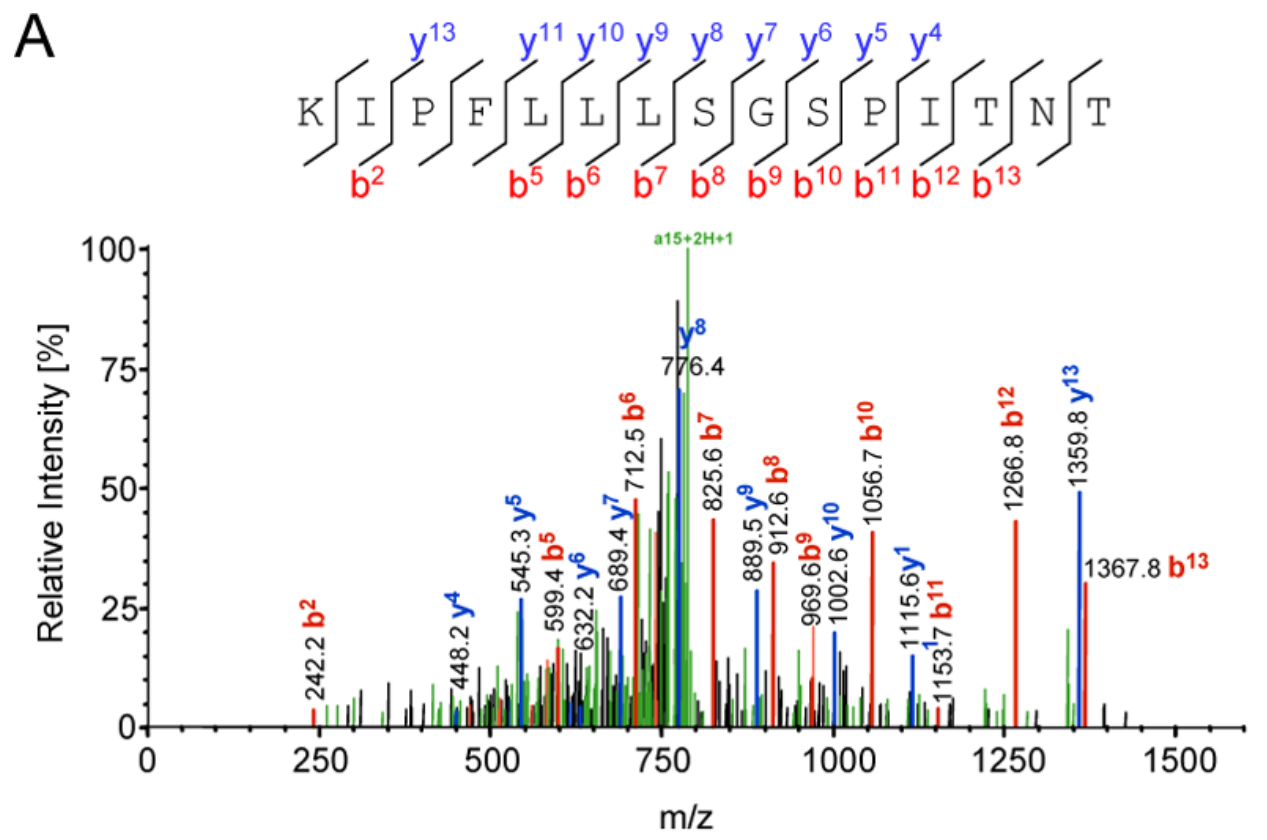

B
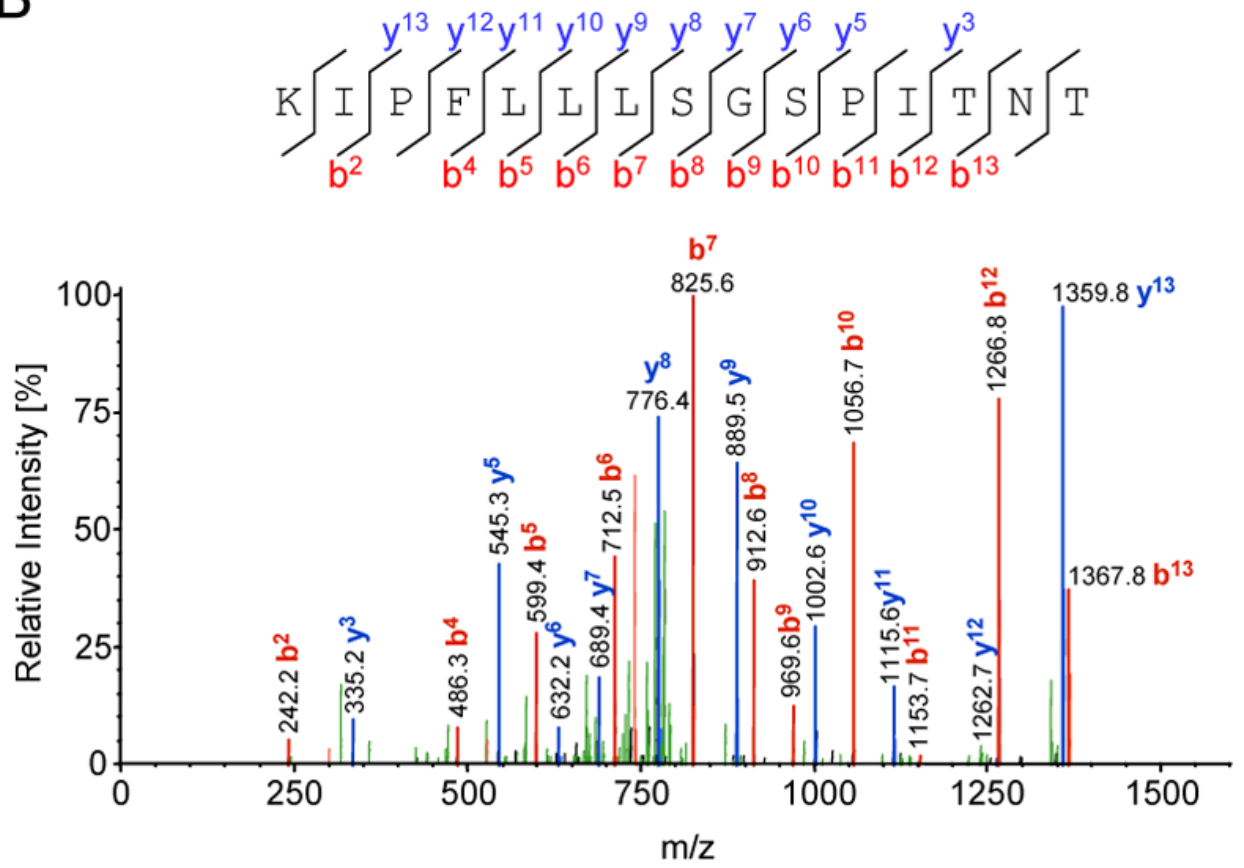

Figure 3. MS/MS spectra of naturally processed HLA-DR1 binding peptide from vaccinia virus D6R protein

(A) CID mass spectrum of candidate ion $\mathrm{m} / \mathrm{z} 801.1$ that has been identified, by SEQUEST ${ }^{\mathrm{TM}}$ (ThermoFisher), as a fragment of vaccinia virus D6R protein. (B) MS/MS spectra from the synthetic peptide with the sequence KIPFLLLSGSPITNT. 

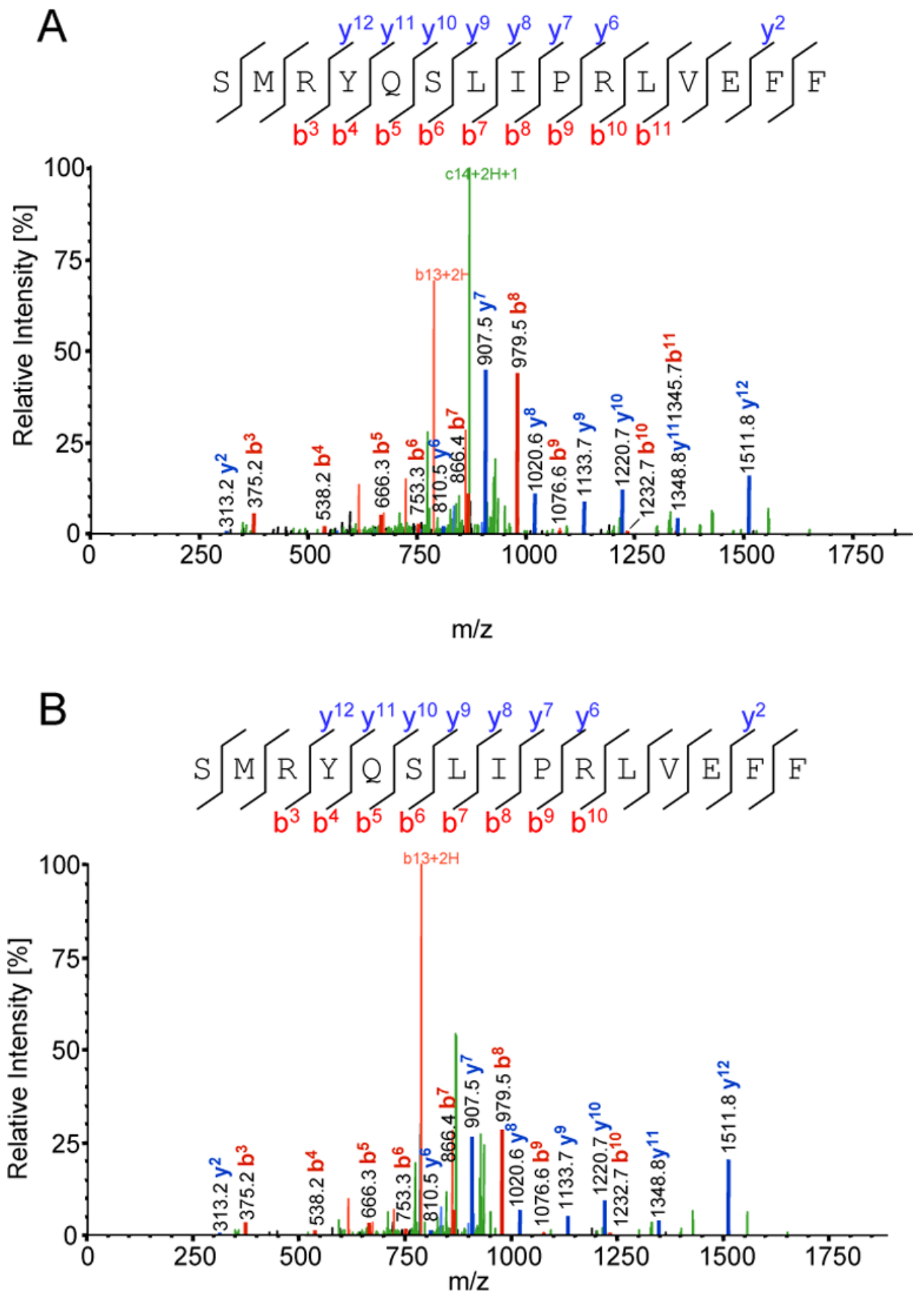

Figure 4. Peptide SMRYQSLIPRLVEFF from vaccinia virus A10L protein is a natural HLADR1 ligand

(A) MS/MS spectrum of $\mathrm{m} / \mathrm{z} 944.0$ that has been identified, using SEQUEST ${ }^{\mathrm{TM}}$ (ThermoFisher), as a fragment of vaccinia virus A10L protein with the sequence SMRYQSLIPRLVEFF. (B) MS/MS spectra from the corresponding synthetic peptide. 


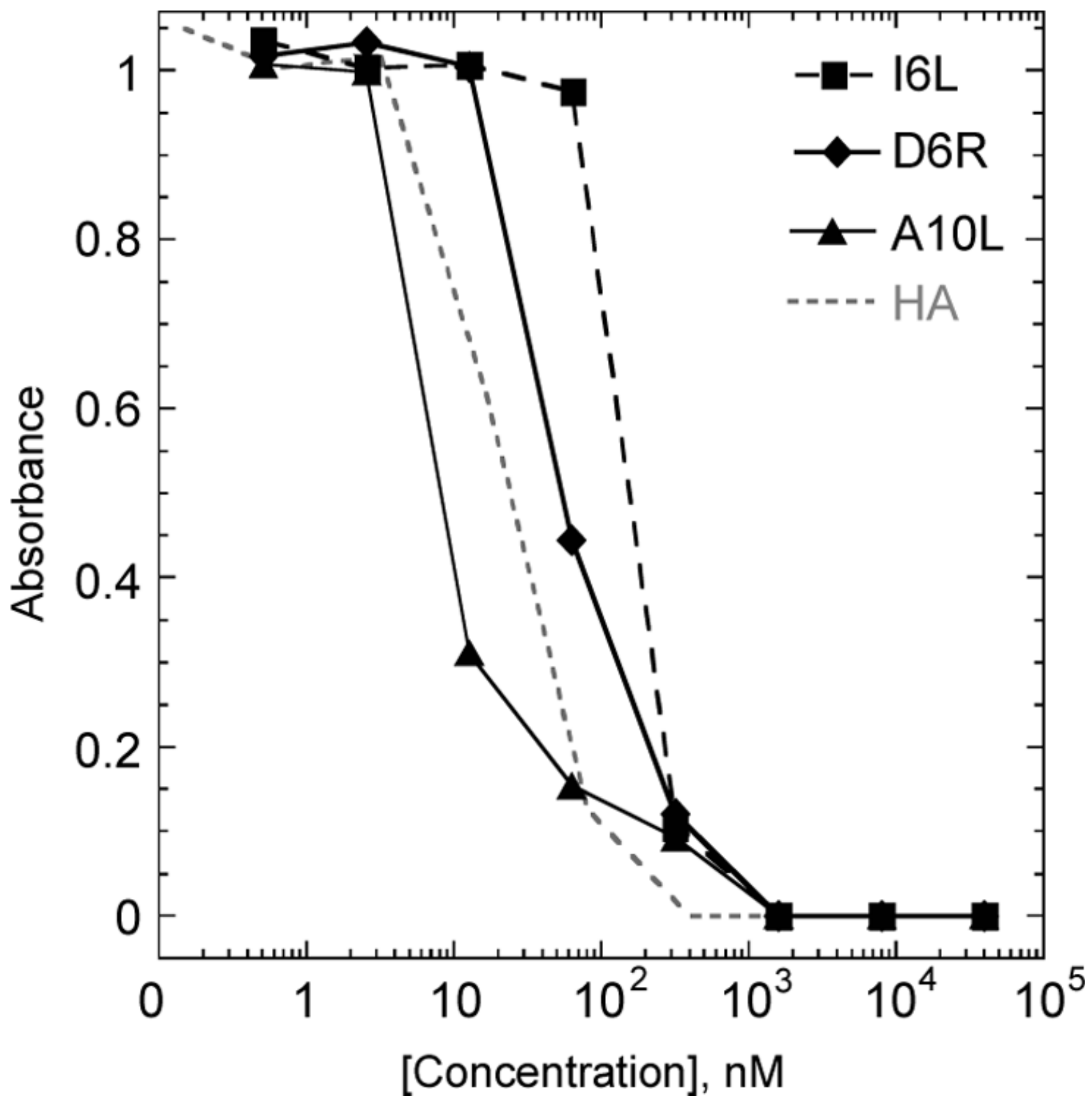

Figure 5.

HLA-DR1 competition binding assay for I6L, D6R and A10L peptides from vaccinia virus. Various concentrations of I6L (squares), D6R (diamonds), A10L (triangle), and control influenza-derived HA (no symbol, dotted line) peptide were used to compete binding of biotinylated HA peptide to soluble HLA-DR1, with binding measured using a streptavidinbased ELISA assay. 

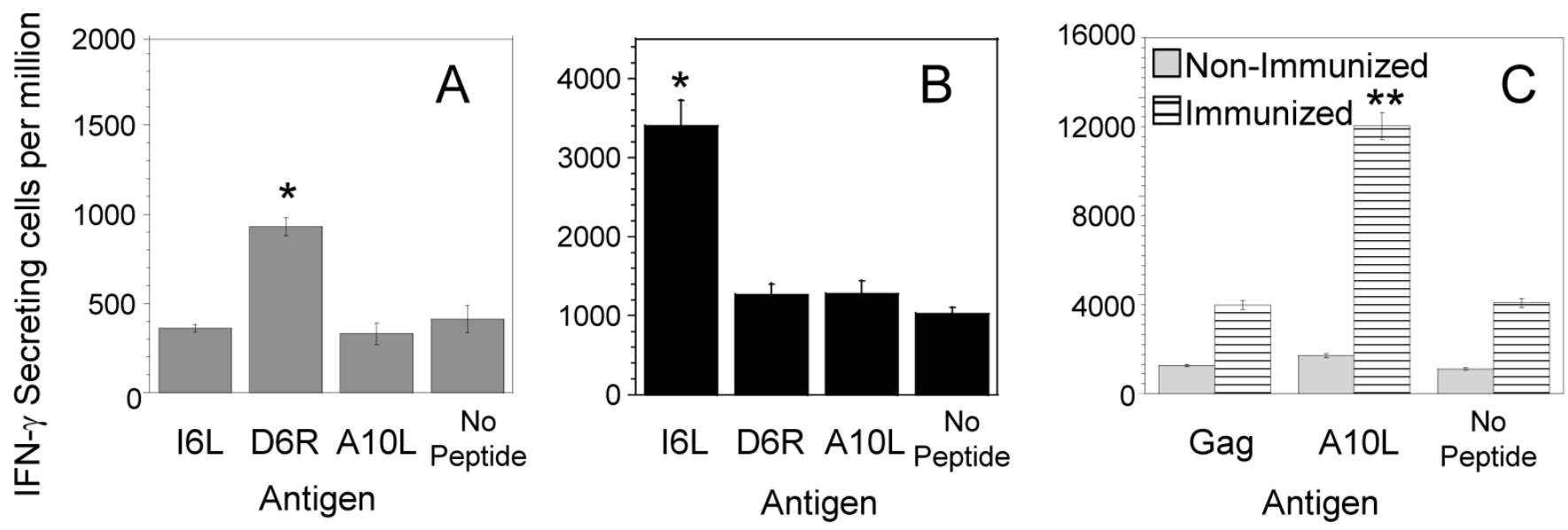

Figure 6. Vaccinia-derived eluted peptides are recognized by $T$ cells elicited by immunization with vaccinia virus

IFN- $\gamma$ ELISPOT response of TCLs generated from a donor after vaccinia immunization.

* Statistically significant IFN- $\gamma$ response $\mathrm{p}<0.001$; * Statistically significant IFN- $\gamma$ response $\mathrm{p}<0.01$. (A) Response to synthetic peptides representing the vaccinia eluted peptides, for a vaccinia-specific TCL generated from peripheral blood approximately 35 years after immunization. (B) T cell responses of a TCL generated from the same donor shown in (A) 13 days after a second booster immunization. (C) IFN- $\gamma$ responses to peptides A10L and to control Gag peptide, for anti-A10L-peptide TCLs derived from blood of a vaccinia vaccinated donor (hatched bars) and from blood of a non-vaccinated donor (clear gray bars). 
Table 1

Naturally processed vaccinia virus peptides eluted from MHC DR-1 molecules isolated from LG2 cells infected with vaccinia virus MVA.

\begin{tabular}{ccccc}
\hline No. & Sequence & Protein of origin & Protein function & IC $_{\mathbf{5 0}}[\mathbf{n M}]$ \\
\hline 1 & IYT YRIIKSSFPVPT & 16L (338-352) & telomere binding protein & $136.3 \pm 6.5$ \\
2 & KIPFLLLSGSPITNT & D6R (157-171) & VETF-1 & $55.6 \pm 1.2$ \\
3 & SMRYQSLIPRLVEFF & A10L $(293-307)$ & major core protein 4a & $6.5 \pm 0.2$ \\
\hline
\end{tabular}




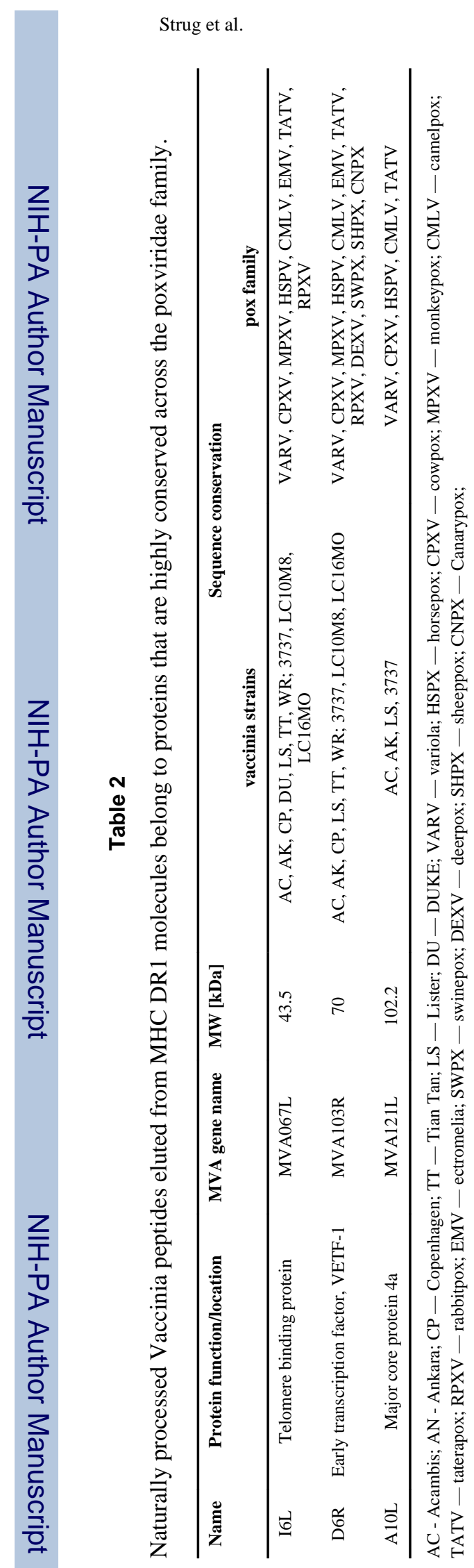

Page 21 